\title{
POLYMORPHISM IN WEST AFRICAN SNAILS
}

\author{
J. F. BARKER
}

Department of Zoology, University of Ibadan, Nigerio

Received 24.iv.67

\section{Introduction}

SHELl colour polymorphism occurs in many terrestrial snails and has been studied intensively in the genus Cepaea. The present paper deals with the genus Limicolaria from the tropical rainforest zone of West Africa (Nigeria). Two species have been studied-L. flammulata (Pfeiffer) and L. aurora (Jay). These snails, like Cepaea, are polymorphic for two shell colour charactersbanding and background colouration. The genetical basis of these polymorphisms and the genetical structure of natural populations have been studied. The hypothesis is advanced that these polymorphisms are controlled by a super-gene and that selection is acting against the coupling arrangements of two of the genes.

\section{Material AND methods}

All the populations studied were in the Western Region of Nigeria. Three or more samples were taken from each population. An attempt was made to collect every snail at each sample site. The breeding techniques will be described elsewhere.

\section{DESGRIPTION OF THE POLYMORPHISMS AND NOTATION}

\section{The banding polymorphism}

In both species some snails have bands of brownish pigment parallel to the long axis of the shell, i.e. across the whorls rather than along them; other snails lack such bands. The bands may be either dark (brownishblack) or light (pale brown) and almost all banded snails can be unequivocally classified in this respect. Hence there are three phenotypes: dark banded, light banded and unbanded. Dark banded snails have normally and perhaps always a grey background colouration.

\section{The background colouration polymorphism}

In $L$. aurora the two phenotypes are pink and grey, which is usually a clear-cut difference. Variation in the darkness of pink is ignored. Banded pink snails are normally light banded. In L. flammulata there seem to be two main colour types-grey and brown, but there are intermediate shades of brown which often make classification difficult.

\section{Notation for genes}

The banding, darkness of banding, and background colouration genes will be referred to as $U, u ; D, d ; G, g$, respectively, the corresponding recessive phenotypes being unbanded, dark and grey. The letters $p$ and $b$ are used as superscripts to distinguish between pink and brown thus: $G^{p}, G^{b}$. 


\section{L. aurora}

\section{Breeding Results}

The results (table 1) are largely consistent with the hypothesis that (i) the background polymorphism is controlled by one gene with two alleles $G^{p}, g$, with pink dominant over grey; (ii) the banding polymorphism is basically controlled by one gene, $U, u$, with banded dominant to unbanded. Thus most of the crosses give a good agreement with the ratios expected on this hypothesis (statistical tests, table 2). The $\mathrm{F}_{1}$ crosses 2, 3 and 4 should

TABLE 1

L. aurora: breeding results

$P_{1}$ GROSSES

Parents

Banded Pink $\times$ Banded Pink

Banded Grey $\times$ Banded Grey

Banded Grey $\times$ Banded Grey

Unbanded Pink $\times$ Unbanded Pink

Unbanded Pink $\times$ Unbanded Grey

Unbanded Pink $\times$ Unbanded Grey

Banded Pink $\times$ Unbanded Pink

Banded Pink $\times$ Unbanded Pink

Banded Pink $\times$ Unbanded Pink

Banded Grey $\times$ Unbanded Grey

Banded Pink $\times$ Banded Grey

Banded Pink $\times$ Banded Grey

Banded Pink $\times$ Unbanded Grey

Banded Pink $\times$ Unbanded Grey

Banded Pink $\times$ Unbanded Grey

Banded Grey $\times$ Unbanded Pink

Banded Grey $\times$ Unbanded Pink

Unbanded Pink* $\times$ Unbanded Grey $\dagger$

Unbanded Pink* $\times$ Unbanded Grey $\uparrow$

Unbanded Pink* $\times$ Unbanded Grey†

\begin{tabular}{|c|c|c|c|c|}
\hline & \multicolumn{4}{|c|}{ Offspring } \\
\hline $\begin{array}{l}\text { Codoss } \\
\text { code } \\
\text { No. }\end{array}$ & $\begin{array}{c}\text { Banded } \\
\text { Pink }\end{array}$ & $\begin{array}{l}\text { Unbanded } \\
\text { Pink }\end{array}$ & $\begin{array}{c}\text { Banded } \\
\text { Grey }\end{array}$ & $\begin{array}{c}\text { Unbanded } \\
\text { Grey }\end{array}$ \\
\hline 56 & 5 & 3 & 2 & - \\
\hline 47 & - & - & 9 & 2 \\
\hline 69 & - & - & 54 & 16 \\
\hline 78 & - & 38 & - & 15 \\
\hline $2 T$ & - & 28 & - & - \\
\hline $2 U$ & - & 17 & - & - \\
\hline 48 & 10 & 10 & 16 & - \\
\hline 60 & - & 4 & - & - \\
\hline 72 & 18 & 36 & 21 & 1 \\
\hline $2 L$ & - & - & 9 & - \\
\hline 57 & 1 & 1 & 7 & - \\
\hline 68 & 5 & 1 & 4 & - \\
\hline 59 & - & 32 & 25 & - \\
\hline 64 & - & 25 & 11 & 5 \\
\hline 73 & $\longrightarrow$ & 19 & 29 & - \\
\hline $2 R$ & 4 & - & 3 & 2 \\
\hline 45 & 16 & 17 & - & - \\
\hline$F_{1}$ GROS & & & & \\
\hline 2 & - & 53 & - & 49 \\
\hline 3 & - & 6 & - & 10 \\
\hline 4 & - & 9 & - & 9 \\
\hline
\end{tabular}

* Unbanded pink parents of these crosses came from the $\mathrm{P}_{1}$ cross $2 U$.

$\dagger$ Unbanded grey parents were from field samples.

especially be noted as providing clear evidence about the background colouration gene. However, two crosses (48 and 64) gave significant departures from expected. Such departures could be caused by faulty experimental technique or by linked recessive lethals. The deviation chisquare for the $3: 1$ ratio of the background colouration gene is significant at the 0.05 level, there being a deficiency of pink. This raises the possibility that homozygous pink may be less viable than the other genotypes, at least under the culture conditions used.

It is necessary to postulate tight linkage to account for the results of crosses such as 59 and 72; so the unbanded grey snails in crosses 64 and 72 should be recombinants. The recombination fraction was estimated as 
3 per cent. with 95 per cent. confidence limits of 1 per cent. and 23 per cent. In making these estimates the data of crosses 59, 64 and 73 were combined, since these crosses are of identical type; for the same reason the results of crosses 48 and 72 were combined.

However, Limicolaria is hermaphrodite, and the possibility cannot be excluded that the unbanded grey offspring of crosses 64 and 72 are the products of self-fertilisation rather than recombinants. The egg-laying parent of all the cross 64 offspring was unbanded grey and the egg-laying parent of the unbanded grey offspring of cross 72 was unbanded and heterozygous for pink. So if self-fertilisation was taking place, it could lead to the production of unbanded grey snails in these crosses. Clearly, if these unbanded grey snails were produced in this way, the intensity of linkage between the two genes would be greater than estimated above. It does, however, seem unlikely that self-fertilisation is taking place since the few snails of both $L$. aurora and $L$. flammulata that were reared without partners did not produce young. Also, the writer knows of no published evidence that self-fertilisation occurs in Limicolaria and related genera.

It is possible that a third gene is involved in the control of the polymorphisms, a gene for darkness of bands. For banded pink snails are normally and perhaps always light banded, while banded grey snails are dark banded. This difference could be caused either by interaction between $G^{p}$ and $U$ or by a closely-linked third gene such as the gene $D, d$, postulated in the next section for $L$. flammulata. The latter hypothesis will be adopted here in order to produce a unified hypothesis to explain the polymorphisms of both species.

\section{L. flammulata}

The banding polymorphism will be dealt with first (results, table 3; statistical tests, table 4). Most of the results of the first generation $\left(\mathrm{P}_{1}\right)$ crosses can be explained by the simple hypothesis of one gene, two alleles and no dominance, so that dark banded and unbanded are homozygotes, and light banded is the heterozygote. For example, light banded $\times$ light banded crosses give a good agreement with the expected $1: 2: 1$ ratio in the $\mathrm{F}_{1}$ (chi-square test 1 ), and a good agreement with expected in the $\mathrm{F}_{2}$.

But the results of $\mathrm{P}_{1}$ crosses 35 and $\mathrm{R}$ cannot be explained in this way. These crosses were dark banded $\times$ unbanded and should therefore have given all light banded offspring, as cross $3 \mathrm{C}$ did. But they gave a $1: 1$ ratio of dark banded:light banded. So some other factor is present in addition to the two alleles postulated. This factor could be either a third allele at the banding locus or a different but closely linked gene, these two possibilities being indistinguishable at present. But the hypothesis of another gene allows the development of a unified hypothesis to explain the polymorphism of both species, so will be adopted here (see next section).

The present hypothesis, then, is that two tightly linked genes are involved in the banding polymorphism: $U, u$, concerned with the production of bands, and $D, d$, concerned with the darkness of the bands. $U$ is needed to produce bands, $d d$ makes the bands dark. Crosses 35 and $\mathrm{R}$ should therefore be $U d / U d \times u D / u d \rightarrow U d / u D$ (light banded) $+U d / u d$ (dark banded). The dark banded offspring should be heterozygous for $U$ but homozygous $d d$ and therefore when mated together should give a 3:1 ratio of dark banded:unbanded, which they did (crosses MB, MC (chi-square test 3)). The rest of 
TABLE 2

L. aurora: statistical tests of the hypothesis that banding and background colouration are each controlled by 1 gene with pink background dominant to grey, banded dominant to unbanded. Data from table 1

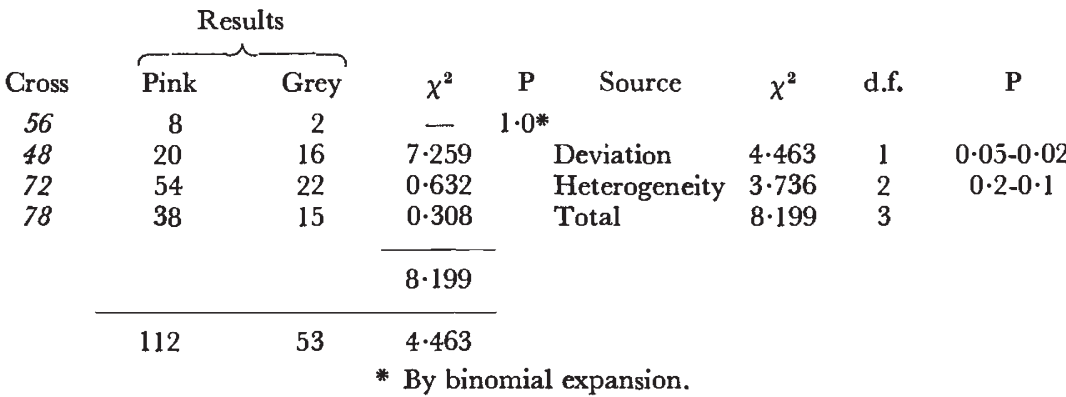

\begin{tabular}{|c|c|c|c|c|c|c|c|}
\hline \multirow[b]{3}{*}{ Cross } & \multicolumn{6}{|c|}{$1: 1$ ratio } & \multirow[b]{3}{*}{$\mathbf{P}$} \\
\hline & \multicolumn{2}{|c|}{ Results } & & \multirow[b]{2}{*}{ Source } & \multirow[b]{2}{*}{$\chi^{2}$} & \multirow[b]{2}{*}{ d.f. } & \\
\hline & Pink & Grey & $\chi^{2}$ & & & & \\
\hline 57 & 2 & 7 & $2 \cdot 778$ & & & & \\
\hline 59 & 32 & 25 & 0.860 & & & & \\
\hline 64 & 25 & 16 & $1 \cdot 976$ & & & & \\
\hline 68 & 5 & 4 & $0 \cdot 112$ & Deviation & $0 \cdot 004$ & 1 & 0.95 \\
\hline 73 & 19 & 29 & $2 \cdot 084$ & Heterogeneity & $9 \cdot 074$ & 8 & $0 \cdot 5-0 \cdot 3$ \\
\hline $2 R$ & 4 & 5 & $0 \cdot 112$ & Total & $9 \cdot 078$ & 9 & \\
\hline 2 & 53 & 49 & 0.156 & & & & \\
\hline 3 & 6 & 10 & $1 \cdot 000$ & & & & \\
\hline \multirow[t]{3}{*}{4} & 9 & 9 & $0 \cdot 000$ & & & & \\
\hline & & & $9 \cdot 078$ & & & & \\
\hline & 155 & 154 & $0 \cdot 004$ & & & & \\
\hline
\end{tabular}

(b) Banding gene-3:1 ratio

\begin{tabular}{ccccc}
\multicolumn{5}{c}{ Results } \\
Cross & $\overbrace{\text { Banded }}$ & Unbanded & $\chi^{2}$ & $\mathbf{P}^{*}$ \\
47 & 9 & 2 & & $0 \cdot 74$ \\
56 & 7 & 3 & & $1 \cdot 00$ \\
57 & 8 & 1 & & $0 \cdot 47$ \\
68 & 9 & 1 & & $0 \cdot 47$ \\
69 & 54 & 16 & 0.172 & $0 \cdot 7-0.5$
\end{tabular}

* Using the binomial expansion except for cross 69 .

\begin{tabular}{|c|c|c|c|c|c|c|c|}
\hline \multirow[b]{2}{*}{ Cross } & \multicolumn{2}{|c|}{ Results } & \multirow[b]{2}{*}{$\chi^{2}$} & \multirow[b]{2}{*}{ Source } & \multirow[b]{2}{*}{$\chi^{2}$} & \multirow[b]{2}{*}{ d.f. } & \multirow[b]{2}{*}{$\mathbf{P}$} \\
\hline & Banded & Unbanded & & & & & \\
\hline 45 & 16 & 17 & 0.030 & & & & \\
\hline 48 & 26 & 10 & $7 \cdot 112$ & & & & \\
\hline 59 & 25 & 32 & $0 \cdot 860$ & Deviation & $0 \cdot 120$ & 1 & $0 \cdot 8-0 \cdot 7$ \\
\hline 64 & 11 & 30 & $8 \cdot 804$ & Heterogeneity & $21 \cdot 600$ & 6 & $<0.01$ \\
\hline 72 & 39 & 37 & $0 \cdot 052$ & Total & $21 \cdot 720$ & 7 & \\
\hline 73 & 29 & 19 & $2 \cdot 084$ & & & & \\
\hline \multirow[t]{3}{*}{$2 R$} & 7 & 2 & $2 \cdot 778$ & & & & \\
\hline & & & $21 \cdot 720$ & & & & \\
\hline & 153 & 147 & $0 \cdot 120$ & & & & \\
\hline
\end{tabular}




\section{TABLE 3}

L. flammulata: breeding results for the banding polymorphism. Snails which appear to be intermediate between two phenotypes scored with a number printed small between the phenotypes concerned

$$
P_{1} \text { CROSSES }
$$

Parents

Dark Banded $\times$ Dark Banded

Light Banded $\times$ Light Banded

Unbanded $\times$ Unbanded

Dark Banded $\times$ Light Banded

Dark Banded $\times$ Unbanded

Light Banded $\times$ Unbanded

Doubtfully Banded $\times$ Doubtfully Banded (see text)

\begin{tabular}{|c|c|c|c|c|}
\hline \multirow[b]{2}{*}{$\begin{array}{c}\text { Cross } \\
\text { code No. }\end{array}$} & \multicolumn{4}{|c|}{ Offspring } \\
\hline & $\begin{array}{c}\text { Dark } \\
\text { Banded }\end{array}$ & & $\begin{array}{c}\text { Light } \\
\text { Banded }\end{array}$ & Unbanded \\
\hline$M B 13$ & 24 & & 0 & 0 \\
\hline SPP4 & 19 & & 0 & 0 \\
\hline$S P P 5$ & 59 & & 0 & 0 \\
\hline$M B 17$ & 26 & & 0 & 0 \\
\hline$\propto 52$ & 2 & & 1 & 1 \\
\hline$I$ & 16 & & 34 & 21 \\
\hline $2 V$ & 17 & & 36 & 14 \\
\hline $2 W$ & 10 & & 37 & 12 \\
\hline $2 r$ & 27 & & 43 & 21 \\
\hline $2 Z$ & 13 & & 30 & 16 \\
\hline 10 & 0 & & 0 & 29 \\
\hline 34 & 0 & & 0 & 13 \\
\hline$Q$ & 0 & & 0 & 33 \\
\hline$\widetilde{S P P} 8$ & 0 & & 0 & 46 \\
\hline 19 & 43 & & 24 & 0 \\
\hline$T$ & 17 & & 10 & 0 \\
\hline$V$ & 10 & 1 & 11 & 0 \\
\hline$B 2$ & 13 & & 24 & 0 \\
\hline$B 7$ & 7 & 1 & 10 & 0 \\
\hline 35 & 24 & 1 & 18 & 0 \\
\hline$R$ & 12 & & 14 & 0 \\
\hline$\alpha 38$ & 0 & & 5 & 0 \\
\hline $3 C$ & 0 & & 63 & 0 \\
\hline$\alpha 49$ & 0 & & 20 & 19 \\
\hline $3 H$ & 1 & & 37 & 33 \\
\hline$O T P$ & 2 & & 4 & 4 \\
\hline
\end{tabular}

$\mathrm{F}_{1}$ Crosses. (A) From $\mathrm{P}_{1}$ cross $I$

Parents

Dark Banded $\times$ Dark Banded

Dark Banded $\times$ Unbanded

Unbanded $\times$ Unbanded

Light Banded $\times$ Unbanded

\begin{tabular}{|c|c|c|c|}
\hline \multirow[b]{2}{*}{$\begin{array}{c}\text { Cross } \\
\text { code No. }\end{array}$} & \multicolumn{3}{|c|}{ Offspring } \\
\hline & $\begin{array}{c}\text { Dark } \\
\text { Banded }\end{array}$ & $\begin{array}{l}\text { Light } \\
\text { Banded }\end{array}$ & Unbanded \\
\hline M8 & 44 & 0 & 0 \\
\hline$M 9$ & 0 & 37 & 0 \\
\hline$M 11$ & 0 & 0 & 76 \\
\hline M37 & 0 & 13 & 20 \\
\hline
\end{tabular}

$\mathrm{F}_{1}$ CRosses.* (B) From $\mathrm{P}_{1}$ crosses 35 and $R$

\section{Parents}

Dark Banded $\times$ Dark Banded

Dark Banded $\times$ Light Banded

Light Banded $\times$ Light Banded

Dark Banded $\times$ Unbanded

\section{Cross} code No.

$$
\begin{gathered}
\text { (35) } M B \\
\text { (35) MC } \\
\text { (35) } M D \\
\dagger(R) M V \\
\text { (R) } M 41 \\
\text { (35) } M 3 K \\
\text { (35) } M 3 P \\
+(35) M 35 L \\
\dagger(R) M R U
\end{gathered}
$$

Offspring

$\overbrace{\begin{array}{c}\text { Dark } \\ \text { Banded }\end{array}}^{\begin{array}{c}\text { Light } \\ \text { Banded }\end{array} \text { Unbanded }}$

\begin{tabular}{rrrc}
49 & & 0 & 10 \\
46 & & 0 & 17 \\
6 & & 6 & 6 \\
35 & 2 & 37 & 19 \\
44 & 1 & 35 & 20 \\
13 & & 27 & 10 \\
10 & 1 & 27 & 13 \\
0 & & 3 & 5 \\
0 & & 37 & 33 \\
& & \multicolumn{2}{c}{ (continued overleaf) }
\end{tabular}


$\mathrm{F}_{2}$ CRosses.* (A) From $\mathrm{F}_{1}$ crosses $M B, M C, M D$

\begin{tabular}{lccccc}
\multicolumn{1}{c}{ Parents } & $\begin{array}{c}\text { Cross } \\
\text { code No. }\end{array}$ & $\overbrace{\text { Dark }}^{\text {Oanded }}$ & $\begin{array}{c}\text { Light } \\
\text { Banded }\end{array}$ & Unbanded \\
Bark Banded $\times$ Dark Banded & $(M B) \mathcal{N} 25$ & 52 & 0 & 15 \\
& $(M B) \mathcal{N} 26$ & 37 & & 0 & 0 \\
& $(M B) \mathcal{N} 28$ & 6 & 3 & 0 & 0 \\
Dark Banded $\times$ Unbanded & $(M C) \mathcal{N} 34$ & 13 & & 0 & 0 \\
Light Banded $\times$ Unbanded & $(M D) \mathcal{N} 50$ & 9 & 1 & 10 & 24
\end{tabular}

$\mathrm{F}_{2}$ CRosses. (B) From $\mathrm{F}_{1}$ cross $M R U$

\begin{tabular}{cccccccc} 
Parents & \multicolumn{7}{c}{ Offspring } \\
Light Banded $\times$ Unbanded & $\begin{array}{c}\text { Cross } \\
\text { code No. }\end{array}$ & $\begin{array}{c}\text { Dark } \\
\text { Banded }\end{array}$ & $\begin{array}{c}\text { Light } \\
\text { Banded }\end{array}$ & $\begin{array}{c}\text { Very } \\
\text { Light } \\
\text { Banded }\end{array}$ & Unbanded \\
& $\mathcal{N} 16$ & 5 & & 4 & 0 & 2 & 10 \\
& $\mathcal{N} 17$ & 25 & 9 & 7 & 7 & 5 & 33 \\
& $\mathcal{N} 18$ & 8 & 2 & 2 & 0 & & 13 \\
& $\mathcal{N} 19$ & 8 & & 4 & 4 & 2 & 16 \\
& $\mathcal{N} 20$ & 2 & 1 & 1 & 0 & 5 \\
& $\mathcal{N} 21$ & 3 & 1 & 4 & 0 & 18
\end{tabular}

* Origin of parents of the $F_{1}$ and $F_{2}$ crosses indicated where necessary with a bracketed cross code number, e.g. (35). Such a number is always placed immediately before the cross code number of the cross concerned.

$\dagger$ Crosses $M V, M R U$ and $M 35 L$ are outcrosses. Their light banded and unbanded parents came from field samples.

the results which run to three generations are in good general agreement with hypothesis.

A discrepancy occurs with crosses MD, M41 and MV. These give a segregation of all three phenotypes as expected and also agree with the expected 3:1 ratio of banded:unbanded (chi-square test 4). But it is also expected that they should give a 2:1:1 ratio of dark banded:light banded: unbanded, and there is a significant departure from this ratio (test 5 ). This is taken simply to mean that some other factor(s) affects the darkness of banding as well as the gene $D, d$, while the hypothesis advanced remains basically valid.

Two other features of the results should be mentioned. One $\mathrm{P}_{1}$ cross, number 19, gave a disturbed ratio, possibly caused by linked recessive lethals (test number 2). With the $\mathrm{F}_{2}$ crosses N16-N21 considerable difficulty was experienced in classifying the offspring into phenotypes. This difficulty may be caused by deterioration of " developmental canalisation " following upon inbreeding (Waddington, 1957), since the progeny are the $F_{2}$ of an outcross. For the purposes of the chi-square test 6 , those snails that were intermediate between dark and light banded were divided equally between these two phenotypes. There was also a fourth phenotype scored in these crosses"very light banded"-in which very faint brown marks occupy the position where bands are normally found on the lower part of the biggest whorl, the rest of the shell being without marks or bands. Such snails were classified as light banded for the chi-square test. This seems justified since one $P_{1}$ 
TABLE 4

L. flammulata: statistical tests based on the hypothesis that banding is controlled by two closely linked genes-U, u (banded, unbanded) and D, d (light banded, dark banded). Data from table 3

Test 1. $P_{1}$ crosses $I, 2 \mathrm{~V}, 2 \mathrm{~W}, 2 \mathrm{~T}, 2 \mathrm{Z}$. Light banded $\times$ light banded

$U d / u D \times U d / u D \rightarrow 1: 2: 1$ ratio dark banded :light banded :unbanded.

\begin{tabular}{|c|c|c|c|c|c|c|c|c|}
\hline \multirow{2}{*}{$\begin{array}{c}\text { Cross } \\
1\end{array}$} & \multicolumn{3}{|c|}{ Results } & \multirow{2}{*}{$\begin{array}{c}\chi^{2} \\
0 \cdot 831\end{array}$} & \multirow{2}{*}{\multicolumn{2}{|c|}{$\chi^{2}$}} & \multirow[t]{2}{*}{ d.f. } & \multirow[t]{2}{*}{$\mathbf{P}$} \\
\hline & 16 & 34 & 21 & & & & & \\
\hline $2 \mathrm{~V}$ & 17 & 36 & 14 & $0 \cdot 643$ & Deviation & $0 \cdot 493$ & 2 & $0 \cdot 8-0 \cdot 7$ \\
\hline $2 W$ & 10 & 37 & 12 & $3 \cdot 950$ & Heterogeneity & $6 \cdot 319$ & 8 & $0 \cdot 7-0 \cdot 5$ \\
\hline $2 r$ & 27 & 43 & 21 & $1 \cdot 066$ & Total & $6 \cdot 812$ & 10 & \\
\hline \multirow[t]{3}{*}{$2 Z$} & 13 & 30 & 16 & $0 \cdot 322$ & & & & \\
\hline & & & & $6 \cdot 812$ & & & & \\
\hline & 83 & 180 & 84 & $0 \cdot 493$ & & & & \\
\hline
\end{tabular}

Test 2. $P_{1}$ crosses $19, T, V, B 2, B 7$. Dark banded $\times$ light banded

Various possibilities $\rightarrow 1: 1$ ratio dark banded:light banded.

\begin{tabular}{|c|c|c|c|c|c|c|}
\hline Cross & & & $\chi^{2}$ & $x^{2}$ & d.f. & $\mathbf{P}$ \\
\hline 19 & 43 & 24 & $5 \cdot 388$ & & & \\
\hline $\mathcal{T}$ & 17 & 10 & $1 \cdot 814$ & Deviation $\quad 0.716$ & 1 & $0 \cdot 5-0 \cdot 3$ \\
\hline$V$ & 10 & 11 & $0 \cdot 048$ & Heterogeneity $10 \cdot 334$ & 4 & $0 \cdot 05-0 \cdot 02$ \\
\hline$B 2$ & 13 & 24 & $3 \cdot 270$ & Total $11 \cdot 050$ & 5 & \\
\hline$B 7$ & 7 & 10 & 0.530 & & & \\
\hline & & & $11 \cdot 050$ & & & \\
\hline & 90 & 79 & $0 \cdot 716$ & & & \\
\hline
\end{tabular}

Test 3. $F_{1}$ crosses $M B, M C ; F_{2}$ cross $\mathcal{N} 25$. Dark banded $\times$ dark banded $U d / u d \times U d / u d \rightarrow 3: 1$ ratio dark banded :unbanded.

\begin{tabular}{|c|c|c|c|c|c|c|c|}
\hline Cross & \multicolumn{2}{|c|}{ Results } & $\chi^{2}$ & \multirow{4}{*}{$\begin{array}{l}\text { Deviation } \\
\text { Heterogeneity } \\
\text { Total }\end{array}$} & \multirow{2}{*}{$\begin{array}{c}\chi^{2} \\
0 \cdot 777\end{array}$} & \multirow{2}{*}{$\begin{array}{c}\text { d.f. } \\
1\end{array}$} & \multirow{2}{*}{$\begin{array}{c}\mathbf{P} \\
0 \cdot 5-0 \cdot 3\end{array}$} \\
\hline$M B$ & 49 & 10 & $2 \cdot 040$ & & & & \\
\hline$M C$ & 46 & 17 & $0 \cdot 132$ & & $1 \cdot 639$ & 2 & $0 \cdot 5-0 \cdot 3$ \\
\hline \multirow[t]{3}{*}{$\mathcal{N} 25$} & 52 & 15 & $0 \cdot 244$ & & $2 \cdot 416$ & 3 & \\
\hline & & & $2 \cdot 416$ & & & & \\
\hline & 147 & 42 & 0.777 & & & & \\
\hline
\end{tabular}

Test 4. $F_{1}$ crosses $M D, M V, M 41$. Dark banded $\times$ light banded

$U d / u d \times U d / u D \rightarrow 3: 1$ ratio banded:unbanded.

\begin{tabular}{|c|c|c|c|c|c|c|c|}
\hline Cross & \multicolumn{2}{|c|}{ Results } & $x^{2}$ & & $\chi^{2}$ & d.f. & $\mathrm{P}$ \\
\hline$M D$ & 12 & 6 & 0.667 & Deviation & $1 \cdot 519$ & 1 & $0 \cdot 3-0 \cdot 2$ \\
\hline$M V$ & 74 & 19 & $1 \cdot 036$ & Heterogeneity & $1 \cdot 517$ & 2 & $0 \cdot 5-0 \cdot 3$ \\
\hline M41 & 80 & 20 & $1 \cdot 333$ & Total & $3 \cdot 036$ & 3 & \\
\hline & & & $3 \cdot 036$ & & & & \\
\hline & 166 & 45 & 1.519 & & & & \\
\hline
\end{tabular}


TABLE 4 (continued)

Test 5. F $F_{1}$ crosses $M D, M V, M 41$. Dark banded $\times$ light banded

$U d / u d \times U d / u D \rightarrow 2: 1: 1$ ratio dark banded :light banded :unbanded.

\begin{tabular}{|c|c|c|c|c|c|c|c|c|}
\hline Cross & & Resu & & $\chi^{2}$ & & $x^{2}$ & d.f. & $\mathrm{P}$ \\
\hline$M D$ & 6 & 6 & 6 & $2 \cdot 000$ & Deviation & $17 \cdot 413$ & 2 & $<0.001$ \\
\hline$M V$ & 35 & 37 & 19 & $11 \cdot 967$ & Heterogeneity & $2 \cdot 322$ & 4 & $0 \cdot 7-0.5$ \\
\hline$M 41$ & 44 & 35 & 20 & $5 \cdot 768$ & Total & $19 \cdot 735$ & 6 & \\
\hline & & & & $19 \cdot 735$ & & & & \\
\hline & 85 & 78 & 45 & $17 \cdot 413$ & & & & \\
\hline
\end{tabular}

This test ignores three banded snails that were classified as intermediate between dark and light banded.

Test $6 . \quad F_{2}$ crosses $\mathcal{N} 16, \mathcal{N} 17, \mathcal{N} 18, \mathcal{N} 19, \mathcal{N} 21, \mathcal{N} 50$. Light banded $\times$ unbanded

$U d / u D \times u d / u D \rightarrow 1: 1: 2$ ratio dark banded :light banded :unbanded.

\begin{tabular}{|c|c|c|c|c|c|c|c|c|}
\hline Cross & \multicolumn{3}{|c|}{ Results } & \multirow{2}{*}{$\begin{array}{c}x^{2} \\
0 \cdot 157\end{array}$} & \multirow{2}{*}{\multicolumn{2}{|c|}{$\chi^{2}$}} & \multirow[t]{2}{*}{ d.f. } & \multirow[t]{2}{*}{$\mathbf{P}$} \\
\hline $\mathcal{N} 16$ & 5 & 4 & 10 & & & & & \\
\hline $\mathcal{N} 17$ & $29 \cdot 5$ & $18 \cdot 5$ & 33 & $5 \cdot 765$ & Deviation & $2 \cdot 259$ & 2 & $0 \cdot 5-0 \cdot 3$ \\
\hline $\mathcal{N} 18$ & 9 & 3 & 13 & $2 \cdot 920$ & Heterogeneity & $10 \cdot 916$ & 10 & $0 \cdot 5-0 \cdot 3$ \\
\hline N19 & 8 & 8 & 16 & $0 \cdot 000$ & Total & $13 \cdot 175$ & 12 & \\
\hline $\mathcal{N} 21$ & $3 \cdot 5$ & $4 \cdot 5$ & 18 & 3.923 & & & & \\
\hline \multirow[t]{3}{*}{$\mathcal{N} 50$} & $9 \cdot 5$ & $10 \cdot 5$ & 24 & 0.410 & & & & \\
\hline & & & & $13 \cdot 175$ & & & & \\
\hline & $64 \cdot 5$ & $48 \cdot 5$ & 114 & $2 \cdot 259$ & & & & \\
\hline
\end{tabular}

cross (OTP) was between two snails with similar faint marks and this gave some dark and some light banded offspring, suggesting that the marks really are bands. However, this phenotype may be caused by the segregation of a different recessive gene and the marks may simply be structural features marking the position of absent bands. Such a phenotype does occur in Cepaea as the recessive phenotype hyalozonate (Lang, 1912; Cain, King and Sheppard, 1960).

It was only possible to classify some of the crosses with respect to background colouration. The results are summarised in table 5, and table 6 gives the statistical tests. It appears that brown is dominant to grey. Thus all grey $\times$ grey crosses gave only grey offspring (crosses $2 \mathrm{Y}, 10,34, \mathrm{~N} 18$ and N21). The brown $\times$ brown cross $Q$ gave only brown offspring, but other brown $\times$ brown crosses gave a 3:1 ratio of brown:grey (crosses $2 \mathrm{~V}, 20$ and probably 16 ). The brown $\times$ grey cross SPP8 gave all brown offspring, but several other crosses of this type gave a $1: 1$ ratio of brown :grey (crosses 2Z, $3 \mathrm{C}, 3 \mathrm{H}, \mathrm{N17}$ and N19). It is likely that the background colouration gene is linked with the banding gene, for it is difficult to account for the results of crosses $2 \mathrm{~V}$ and $2 \mathrm{Z}$ without this.

Most or all of the very light banded and doubtfully banded snails of crosses N17 and N19 had a brownish background colouration, and it is difficult to account for this if these band-like marks really are bands. For letting $G^{b}$ and $g$ stand for the alleles of the background colouration gene, these crosses should be $U d g / u D G^{b} \times u D g / u d g$ (without implying gene order 
on the chromosome). So banded brown offspring would be cross-overs and the reciprocal cross-over class unbanded grey should appear. Now unless the two unbanded snails of cross 19 that could not be classified for background colour are in fact grey, this reciprocal class did not occur.

Finally, it should be pointed out that dark banded brown snails did not occur in the breeding programme and the writer has never seen an unequivocal example of such a phenotype in natural populations. Perhaps the combination $U-d d G^{b}$ - is lethal.

\section{Comparison between the species}

On the hypothesis that there are three linked loci, $u, d$ and $g$ involved in the polymorphisms, each with two alleles, there are eight theoretically possible chromosomal arrangements of which five may be identified in the crosses already discussed (table 7). For example, the L. flammulata cross 3C must be $U d g / U d g \times u D G^{b} / u D g \rightarrow U d g / u D G^{b}+U d g / u D g$, so that the chromosomes $U d g, u D G^{b}$ and $u D g$ are identified.

\section{TABLE 5}

L. flammulata: breeding results for the background polymorphism. Offspring of each cross classified in two rows: upper, brown snails; lower, grey. Snails which appear to be intermediate between two phenotypes scored with a number printed small between the phenotypes concerned

$P_{1}$ crosses

\section{Parents}

Light Banded Brown

Light Banded Brown

$\times$ Light Banded Grey

Light Banded Grey

$\times$ Light Banded Brown

Light Banded Grey

Unbanded Grey

$\times$ Unbanded Grey

$\times$ Ubanded Grey

Unbanded Grey

$\times$ Unbanded Brown

$\times$ Unbanded Brown

Unbanded Brown

$\times$ Unbanded Grey

$\times$ Dark Banded Grey

Unbanded Brown

Light Banded Grey

$\times$ Unbanded Brown

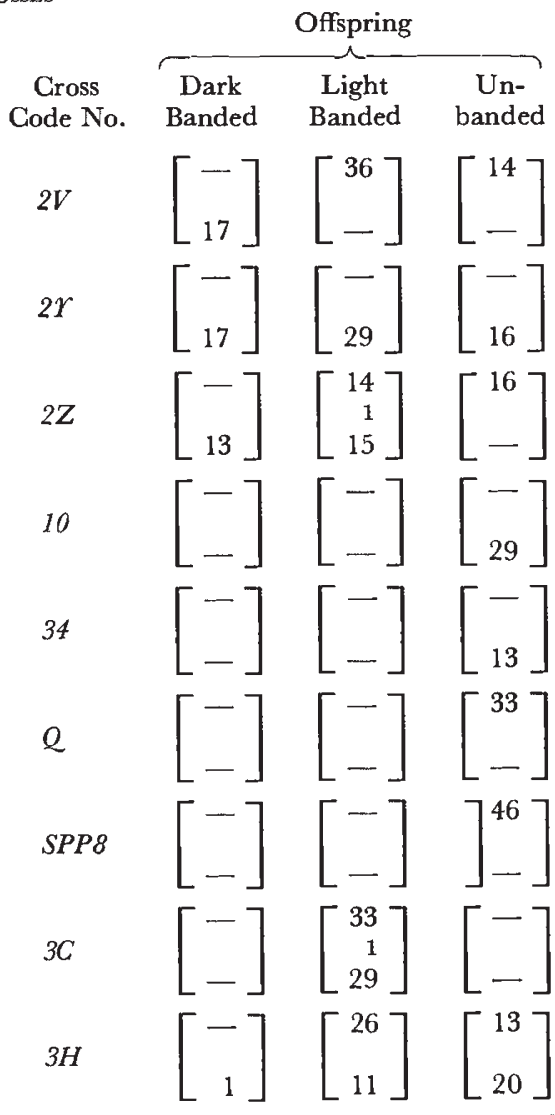

(continued overleaf) 
TABLE 5 (continued)

Parents
\[ \begin{array}{l}\text { Light Banded Brown } \\ \text { Unbanded Brown }\end{array} \]
$\times \begin{aligned} & \text { Light Banded, Doubtful Brown } \\ & \text { Unbanded Brown }\end{aligned}$
$\times \begin{aligned} & \text { Light Banded Brown } \\ & \text { Unbanded Grey }\end{aligned}$
$\times \begin{aligned} & \text { Light Banded Brown } \\ & \text { Unbanded Grey }\end{aligned}$
$\times \begin{aligned} & \text { Light Banded Grey } \\ & \text { Unbanded Grey }\end{aligned}$
$\times \begin{aligned} & \text { Light Banded Grey } \\ & \text { Unbanded Grey }\end{aligned}$

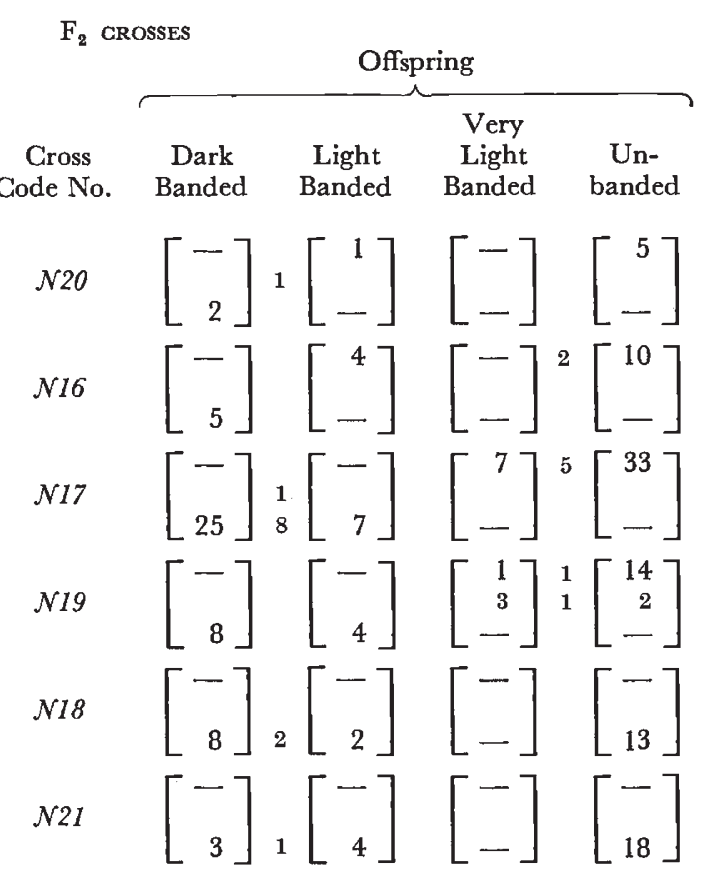

* All the parents of the $\mathrm{F}_{2}$ crosses were offspring of the $\mathrm{F}_{1}$ cross $M R U$ (see table 3).

Of these five arrangements, all are found in L. flammulata but only three in $L$. aurora (table 7 ). This difference is related to the presence of the phenotype light banded grey in L. flammulata and its apparent absence in $L$. aurora. For light banded grey will only occur in the presence of both $U$ and $D$ and the absence of $G$, and in $L$. aurora, $D$ has only been found in the chromosome $u D G$, i.e. coupled with $G$. So all light banded snails in $L$. aurora will have the pink background colour. But the two chromosomes $U D g$ and $u D g$, which are found in $L$. flammulata and not in $L$. aurora, have $D$ coupled to $g$, allowing the production of the light banded grey phenotype.

Table 7 shows that the only chromosomes not yet definitely identified on the above hypothesis are $U D G, U d G$ and $u d G$, although their reciprocal arrangements occur. Hence there is no clear evidence from the breeding results for the existence of the $U-G$ coupling arrangements.

\section{Population genetics}

\section{L. aurora}

The population data is summarised in table 8 , where for each population all the samples have been pooled together. It can be seen that the least common phenotype is usually light banded pink. Considering background colouration only, the commonest phenotype is usually grey, which varies in frequency from 0.4 (Orile Odo) to 1.0 (Oluwo). Taking the banding polymorphism by itself, unbanded is usually the commonest phenotype, varying in frequency from 0.28 (Epe) to 0.94 (Iperu). The recessive phenotypes, then, tend to be the commonest, but they are not always so. It should be 
pointed out that the samples from two populations, Odo Ona and Abu Uku 1, contained a high proportion of L. flammulata (see table 8). Although most snails can be readily classified as either aurora or flammulata, some prove difficult to classify, so the results from these two populations should be treated with caution.

Tests were performed to see if the polymorphisms are in Hardy-Weinberg equilibrium. For this purpose the gene $D, d$ was ignored, since $D$ is probably always coupled with $G^{p}$ in $L$. aurora and since the breeding results for this

\section{TABLE 6}

L. flammulata: statistical tests of the hypothesis that background colouration is controlled by one gene with brown dominant to grey. Data from table 5

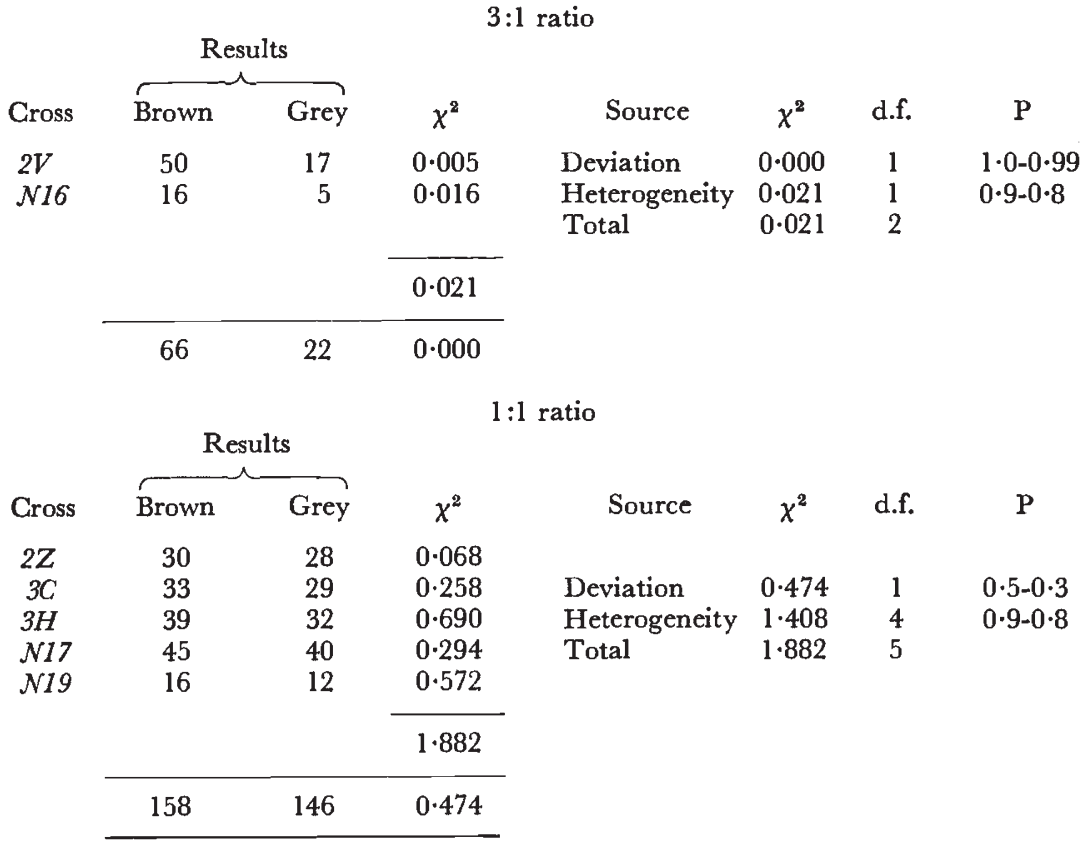

TABLE 7

Chromosomes found among breeding programme snails assuming the three gene hypothesis is true

Possible chromosomes*

L. aurora

May occur $\uparrow$

Does not occur

Does not occur

Found

Found

May occur

May occur

Found
L. flammulata

May occur

Found

Does not occur

Found

Found

May occur

Found

Found

* No order of the genes along the chromosome is implied.

$\dagger$ "May occur" means that the breeding results do not provide critical evidence for presence or absence. 
TABle 8

Summary of samples from natural populations

L. aurora

Numbers*

\begin{tabular}{|c|c|c|c|c|c|c|}
\hline $\begin{array}{c}\text { Banded } \\
\text { Pink }\end{array}$ & $\begin{array}{c}\text { Banded } \\
\text { Grey }\end{array}$ & $\begin{array}{c}\text { Un- } \\
\text { banded } \\
\text { Pink }\end{array}$ & $\begin{array}{c}\text { Un- } \\
\text { banded } \\
\text { Grey }\end{array}$ & Total & $\begin{array}{c}f \dagger \\
\text { Un- } \\
\text { banded }\end{array}$ & $\begin{array}{c}f \ddagger \\
\text { Grey }\end{array}$ \\
\hline
\end{tabular}

$\begin{array}{lrlrrrrrrrr}\text { Aba Ajao } & 6 & - & 14 & 30 & - & 11 & 61 & 0 \cdot 67 & 0 \cdot 41 & 8 \\ \text { Odo Ona } & 10 & 1 & 21 & 33 & 3 & 17 & 85 & 0 \cdot 62 & 0 \cdot 47 & 47 \\ \text { Orile Odo } & 72 & - & 84 & 140 & 5 & 53 & 354 & 0 \cdot 56 & 0 \cdot 39 & - \\ \text { Abanla 1 } & 5 & - & 24 & 17 & - & 17 & 63 & 0 \cdot 54 & 0 \cdot 65 & - \\ \text { Abanla 2 } & 7 & - & 16 & 15 & - & 12 & 50 & 0 \cdot 54 & 0 \cdot 56 & - \\ \text { Abu Uku 1 } & 6 & - & 17 & 15 & - & 9 & 47 & 0 \cdot 51 & 0 \cdot 55 & 70 \\ \text { Abu Uku 2 } & 4 & - & 7 & 25 & 2 & 28 & 66 & 0 \cdot 83 & 0 \cdot 55 & 8 \\ \text { Odetola } & 107 & 20 & 403 & 310 & 24 & 454 & 1318 & 0 \cdot 60 & 0 \cdot 67 & 26 \\ \text { Oluwo } & - & - & 47 & - & - & 35 & 82 & 0 \cdot 43 & 1 \cdot 00 & - \\ \text { Ipara } & 27 & 4 & 57 & 29 & 3 & 25 & 145 & 0 \cdot 39 & 0 \cdot 59 & - \\ \text { Iperu } & 2 & - & 4 & 42 & - & 52 & 100 & 0 \cdot 94 & 0 \cdot 56 & - \\ \text { Shagamu-Ijebu } & \mathbf{8} & - & 10 & 36 & 2 & 25 & 81 & 0 \cdot 78 & 0 \cdot 44 & - \\ \quad \text { Rd. } & & & & & & & & & & \\ \text { Itele } & 4 & - & 84 & 5 & 4 & 86 & 183 & 0.52 & 0.95 & 5 \\ \text { Epe } & 2 & - & 156 & - & - & 60 & 218 & 0 \cdot 28 & 0.99 & 9\end{array}$

\section{L. flammulata}

Numbers*

\begin{tabular}{|c|c|c|c|c|c|c|c|}
\hline Locality & $\begin{array}{c}\text { Banded } \\
\text { Dark }\end{array}$ & & $\begin{array}{c}\text { Banded } \\
\text { Light }\end{array}$ & & abanded & Total & $\underset{\text { Unbanded }}{f \|}$ \\
\hline Balogun & 176 & - & 183 & 2 & 58 & 419 & $0 \cdot 14$ \\
\hline Majeroku & 578 & - & 111 & 1 & 8 & 698 & 0.01 \\
\hline Iroku & 45 & 3 & 92 & - & 36 & 176 & $0 \cdot 20$ \\
\hline Ibadan 1 & 15 & 一 & 22 & 1 & 7 & 45 & $0 \cdot 16$ \\
\hline Ibadan 2 & 76 & 1 & 156 & - & 65 & 298 & 0.22 \\
\hline Ibadan 3 & 9 & 2 & 45 & - & 29 & 85 & 0.34 \\
\hline Ibadan 4 & 26 & - & 28 & - & 16 & 70 & 0.23 \\
\hline Ibadan 5 & 19 & - & 29 & - & 6 & 54 & $0 \cdot 11$ \\
\hline Odolagaye & 70 & - & 17 & - & 3 & 90 & 0.03 \\
\hline Oshunmaiyegan 1 & 130 & 9 & 46 & - & 5 & 190 & 0.03 \\
\hline Oshunmaiyegan 2 & 362 & 5 & 58 & - & 5 & 430 & $0 \cdot 01$ \\
\hline Omo & 199 & 3 & 3 & - & - & 205 & $0 \cdot 00$ \\
\hline Achilla & 342 & 25 & 38 & - & 2 & 407 & $0 \cdot 00$ \\
\hline Onishere & 1495 & 8 & 336 & 3 & 41 & 1883 & $0 \cdot 02$ \\
\hline Ashipa & 134 & 2 & 31 & 2 & 4 & 173 & $0 \cdot 02$ \\
\hline
\end{tabular}

* In the "Numbers" sections, unlabelled columns are for snails that could not be definitely assigned to one particular phenotype and are therefore placed between the two phenotypes concerned. The totals include such snails.

$\dagger$ The frequency $(f)$ of unbanded makes use of the totals as given.

$\ddagger$ The frequency of grey makes use of the totals minus snails that could not be definitely classed as either pink or grey.

\$ The column headed "None aurora snails" is the number of specimens of flammulata in the corresponding aurora sample; such snails are not included in the "Total " column.

II Snails that could not definitely be classed as either banded or unbanded were omitted from the total before the frequency $(f)$ of unbanded was calculated. 
species can be explained without it. Gene frequencies were estimated (Li, 1955) and then used to calculate expected phenotype frequencies. The chisquare test was then employed to test if the observed values are consistent with the Hardy-Weinberg expectations. There was a significant departure from the expected proportions in the following populations: Aba Ajao, Odo Ona, Orile Odo, Abanla 1, Abu Uku 1 and Odetola. In all these populations there were fewer banded pinks and unbanded greys than expected. In five other populations there were non-significant deviations in the same directions. Details are given in table 9 for Odetola, the population from which most data has been obtained.

TABLE 9

L. aurora: genetics of the Odetola population. The gene $\mathrm{D}, \mathrm{d}$ is ignored

Gene frequencies

$U, 0 \cdot 2256 u, 0 \cdot 7744 \quad G^{p}, 0 \cdot 1798 \quad g, 0.8202$

Hardy-Weinberg equilibrium chi-square test

Banded Banded Unbanded Unbanded

Pink Grey Pink Grey

$\begin{array}{lllll}\text { Observed } & 107 & 403 & 310 & 454\end{array}$

$\begin{array}{llll}\text { Expected } & 166.89 & 343.09 & 250.09\end{array}$

Chi-square $=53 \cdot 29$. d.f $=4-2-1=1 . \quad P=<0 \cdot 001$.

\begin{tabular}{|c|c|c|c|c|}
\hline \multicolumn{5}{|c|}{ Frequencies of chromosomes } \\
\hline & $U G^{p}$ & $U g$ & $u G^{p}$ & $u g$ \\
\hline Expected on Hardy-Weinberg & 0.0405 & $0 \cdot 1850$ & $0 \cdot 1393$ & $0 \cdot 6351$ \\
\hline Estimated by chromosome counting & $0 \cdot 0024$ & $0 \cdot 2232$ & $0 \cdot 1774$ & $0 \cdot 5970$ \\
\hline
\end{tabular}

Hardy-Weinberg

Estimated by counting

Hardy-Weinberg

Estimated by counting

Frequencies of genotypes

\begin{tabular}{lcccc}
\multicolumn{5}{c}{ Genotype } \\
UG/UG & $U G / U g$ & $U G / u G$ & $U G / u g$ & $U g / u G$ \\
0.0016 & 0.0150 & 0.0113 & 0.0515 & 0.0515 \\
0.0000 & 0.0011 & 0.0009 & 0.0029 & 0.0792 \\
& & & & \\
$U g / U g$ & $U g / u g$ & $u G / u G$ & $u G / u g$ & $u g / u g$ \\
0.0342 & 0.2350 & 0.0194 & 0.1769 & 0.4034 \\
0.0498 & 0.2665 & 0.0315 & 0.2118 & 0.3564
\end{tabular}

\section{L. flammulata}

The population data is summarised in table 8; only the banding polymorphism is recorded, since it was normally difficult to classify for background colouration. The least common phenotype is unbanded, its frequency only exceeding 0.3 in one population (Ibadan $3, f=0.34$ ). This is in marked contrast to $L$. aurora, where unbanded is frequently the commonest phenotype, with a frequency that only falls below 0.4 in two populations. Since the populations of both species are located in various parts of the same large area of Western Nigeria, this difference in the frequency of unbanded may well be a real difference between the species. And since the frequency of the gene $u$ is the square root of the unbanded frequency, it looks as if the two species may differ in the frequencies of the $U$ and $u$ alleles. 
Although it is normally difficult to classify L. flammulata for background colour, it was possible to do this with one population, Balogun. When the data for this population was analysed, the results were essentially the same as those obtained with $L$. aurora: i.e. there are similar departures from the Hardy-Weinberg equilibrium frequencies (see table 10).

TABLE 10

L. flammulata: genetics of the Balogun population. The gene $\mathrm{D}, \mathrm{d}$ is ignored

Gene frequencies

$U, 0.6295 u, 0.3705 G^{b}, 0.1274 \quad g, 0.8726$

Hardy-Weinberg equilibrium chi-square test

Banded Banded Unbanded Unbanded

Brown Grey Brown Grey

$\begin{array}{lllll}\text { Observed } & 66 & 292 & 33 & 24 \\ \text { Expected } & 85.41 & 272 \cdot 61 & 13 \cdot 61 & 43.37\end{array}$

Chi-square $=42 \cdot 06$. d.f. $=4-2-1=1 . \quad P=<0.001$.

\begin{tabular}{lcccc}
\multicolumn{4}{c}{ Frequencies of chromosomes } \\
& $U G^{b}$ & $U g$ & $u G^{b}$ & $u g$ \\
Expected on Hardy-Weinberg & 0.0802 & 0.5493 & 0.0472 & 0.3233 \\
Estimated by chromosome counting & 0.0000 & 0.6302 & 0.1276 & 0.2422
\end{tabular}

\section{The action of selection}

It seems highly probable that in both species the departures from HardyWeinberg equilibrium are caused by natural selection, and evidence will now be presented that they are associated with a reduction in the frequencies of the coupling arrangements $U G^{b}$ and $u g$ from the Hardy-Weinberg equilibrium frequencies.

(i) In L. aurora, the frequencies of the four chromosomal arrangements $U G^{p}, U g, u G^{b}$ and $u g$ have been estimated for each population using the iterative process of "gene counting" which is applicable (as here) to chromosome counting (Ceppellini, Siniscalco and Smith, 1955; Smith 1956). The calculation is a very long one, so the Ibadan University IBM computer was programmed to carry it out. The calculations were performed to six decimal places of accuracy to avoid " round off" errors. The results are shown in table 11, and estimates of genotype frequencies for the Odetola population are shown in table 9; table 11 also gives for comparison the frequencies of the coupling arrangements as expected on the basis of HardyWeinberg equilibrium.

It can be seen that the frequency of the $U G^{b}$ chromosome is very low or zero in all populations. Also the frequencies of both the coupling arrangements are usually lower than the Hardy-Weinberg equilibrium values. Table 9 shows that within the light banded pink phenotype, all genotypes containing the $U G^{p}$ chromosome have very much lower values than expected, while the repulsion double heterozygote $U g / u G^{b}$ is slightly more frequent than expected, and is much commoner than the coupling double heterozygote $U G^{p} / u g$. Table 10 shows that the $U G$ chromosome is also rare in the Balogun population of L. flammulata. 
(ii) All ten light banded pink parents in the $L$. aurora breeding programme are double heterozygotes, since both unbanded and grey snails segregate out in their progenies. Further, eight of these parents must be in the repulsion phase, the phase of the remaining two being unknown (one parent of cross 56 and the light banded pink parent of cross 60 ). In the absence of selection one would expect a 1:1 ratio of coupling and repulsion phases, so the probability of getting eight out of ten may be calculated using the binomial expansion. Since there are already grounds (section (i)) for suspecting that the departure from the $1: 1$ ratio will be in favour of the repulsion phase, the appropriate test is the " one-tail" one. The probability is $0.0547-i . e . \bumpeq 0.05$, which is on the verge of formal significance. Since

TABLE 11

L. aurora: estimated frequencies of chromosomes in natural populations compared with Hardy-Weinberg equilibrium frequericies. The gene $\mathrm{D}, \mathrm{d}$ is ignored

\begin{tabular}{|c|c|c|c|c|c|c|}
\hline \multirow[b]{3}{*}{ Population } & \multicolumn{6}{|c|}{ Chromosome frequencies } \\
\hline & \multicolumn{4}{|c|}{ Estimated by counting } & \multicolumn{2}{|c|}{$\begin{array}{l}\text { Hardy-Weinberg } \\
\text { equilibrium (coupling } \\
\text { chromosomes only) }\end{array}$} \\
\hline & $U G^{p}$ & $U g$ & $u G^{p}$ & $u g$ & $U G^{p}$ & $u g$ \\
\hline Aba Ajao & $0 \cdot 0000$ & $0 \cdot 1833$ & $0 \cdot 3661$ & 0.4505 & 0.0649 & 0.5248 \\
\hline Odo Ona & $0 \cdot 0000$ & $0 \cdot 2157$ & $0 \cdot 3170$ & 0.4673 & $0 \cdot 0676$ & 0.5382 \\
\hline Orile Odo & $0 \cdot 0195$ & $0 \cdot 2368$ & $0 \cdot 3539$ & $0 \cdot 3897$ & $0 \cdot 0958$ & 0.4659 \\
\hline Abanla 1 & $0 \cdot 0000$ & $0 \cdot 2683$ & $0 \cdot 1954$ & $0 \cdot 5363$ & $0 \cdot 0513$ & 0.5926 \\
\hline Abanla 2 & 0.0067 & $0 \cdot 2584$ & $0 \cdot 2449$ & 0.4899 & 0.0668 & 0.5499 \\
\hline Abu Uku 1 & $0 \cdot 0000$ & $0 \cdot 2884$ & $0 \cdot 2589$ & $0 \cdot 4528$ & $0 \cdot 0732$ & 0.5316 \\
\hline Abu Uku 2 & 0.0119 & $0 \cdot 0781$ & $0 \cdot 2486$ & 0.6614 & $0 \cdot 0234$ & $0 \cdot 6731$ \\
\hline Odetola & $0 \cdot 0024$ & $0 \cdot 2232$ & $0 \cdot 1774$ & 0.5970 & $0 \cdot 0405$ & 0.6351 \\
\hline Oluwo & $0 \cdot 0000$ & $0 \cdot 3467$ & $0 \cdot 0000$ & $0 \cdot 6533$ & 0.0000 & $0 \cdot 6533$ \\
\hline Ipara & 0.0292 & $0 \cdot 3452$ & $0 \cdot 1999$ & 0.4256 & 0.0859 & 0.4822 \\
\hline Iperu & $0 \cdot 0032$ & $0 \cdot 0272$ & $0 \cdot 2484$ & $0 \cdot 7211$ & $0 \cdot 0077$ & 0.7256 \\
\hline Shagamu-Ijebu Rd. & $0 \cdot 0182$ & $0 \cdot 1031$ & $0 \cdot 3162$ & 0.5625 & $0 \cdot 0405$ & 0.5850 \\
\hline Itele & $0 \cdot 0056$ & $0 \cdot 2814$ & $0 \cdot 0199$ & $0 \cdot 6931$ & $0 \cdot 0074$ & 0.6949 \\
\hline Epe & $0 \cdot 0046$ & $0 \cdot 4701$ & $0 \cdot 0000$ & 0.5246 & $0 \cdot 0022$ & 0.5222 \\
\hline
\end{tabular}

selection seems to be acting in a similar way in both $L$. aurora and $L$. flammulata, it seems legitimate to combine the data of the two species when considering the proportions of coupling and repulsion phases. In L. flammulata, all seven of the light banded brown parents must be doubly heterozygous and at least six of these must be in the repulsion phase. Summing over species gives a minimum of fourteen repulsions out of a total of seventeen double heterozygotes. This gives a probability of $<0.01$.

(iii) In $L$. aurora, the rarity of the $U G^{p}$ chromosome may also be shown by ignoring it and treating the other chromosomes as a system of multiple alleles. Representing the chromosomes $U g, u G^{p}$ and $u g$ as alleles $p, q$ and $r$, respectively, the composition of the phenotypes becomes: banded pink, $2 p q$; banded grey, $p^{2}+2 p r ;$ unbanded pink, $q^{2}+2 q r ;$ unbanded grey, $r^{2}$. The frequencies of $p, q$ and $r$ may be estimated and used to calculate phenotype frequencies expected on the basis of Hardy-Weinberg equilibrium. When this is done, there is normally a very good agreement between observed and expected frequencies. Thus with the Odetola population, when the gene frequencies are calculated by the method used by Taylor and Prior (1938), 
the chi-square is 0.217 , which with one degree of freedom gives a probability of $0.7-0.5$; estimating gene frequencies by Fisher's method (described in Race and Sanger, 1962) leads to a chi-square of 0.234 , again with a probability of $0 \cdot 7-0 \cdot 5$.

\section{Discussion}

There are a number of similarities between the shell colour polymorphisms of Limicolaria and Cepaea. In Cepaea the genes for banding, background colouration, and almost certainly for "spread bands" are tightly linked to form a super-gene (Fisher and Diver, 1934; Cain and Sheppard, 1957; Cain, King and Sheppard, 1960). In Limicolaria the genes for banding and background colouration are probably tightly linked and there may be a third linked gene which is concerned with the darkness of bands. The evidence therefore suggests that the polymorphisms in Limicolaria are under the control of a super-gene, as they are in Cepaea. It has, of course, long been recognised that the genes controlling a polymorphism are often linked (Haldane, 1930; Sheppard, 1953). There are other similarities between the genera. In the background polymorphism, pink and brown are dominant, in Cepaea over yellow (Lamotte, 1951 ; Cain, King and Sheppard, 1960), in Limicolaria over grey. Further, in Cepaea there are probably differences between species in the chromosomal arrangements that occur (Professor P. M. Sheppard, personal communication), and if the three gene hypothesis advanced in the present paper is true, similar differences occur in Limicolaria.

In the banding polymorphism, banded is dominant to unbanded in Limicolaria but the reverse is true of Cepaea. However, the bands of Limicolaria are probably not homologous with those of Cepaea because they have a different orientation on the shell, presupposing a different pattern of activity and distribution of the pigment-producing cells. Thus the bands in Limicolaria run across the whorls, those in Cepaea along the whorls. There is, however, a rare phenotype in Cepaea, the variety undulata, with bands running across the whorls (Lang, 1912; Lamotte, 1951). Lamotte thinks this is a variant of the phenotype " pale bands", and there is evidence that the gene for pale bands is closely linked to the background colouration and banding genes (Dr L. M. Cook, personal communication). The bands of Limicolaria may then be homologous to those of the variety undulata.

In the polymorphisms of Limicolaria selection seems to be acting against coupling phases, particularly of the dominant genes. In L. aurora it has been estimated by chromosome counting that the frequency of the $U G^{p}$ chromosome is less than 0.02 in all populations except Ipara, where its frequency is about 0.03 . Indeed, the frequency of this chromosome is so low that when it is ignored and the other chromosomes treated as a system of multiple alleles, a very good agreement between observed and expected phenotype frequencies is obtained. The situation seems to be similar to that in the colour pattern polymorphism of the Grouse Locust Paratettix texanus, where the coupling arrangements of the various dominant genes are so rare as to be virtually absent (Fisher, 1939).

The magnitude of the selection pressures against coupling phases in Limicolaria is uncertain, since it depends upon the tightness of linkage. Now, the recombination fraction for $U, u$ and $G^{p}, g$, was estimated as 3 per cent., but it was pointed out that the linkage would be much tighter than this if the snails classed as recombinants were in fact the products of self-fertilisation. 
In the absence of suitable genetical or cytological markers, it is not possible to decide whether self-fertilisation has taken place or not. But even with 3 per cent. recombination the selection pressures are probably small.

Where selection acts against the coupling phases of two genes and in favour of the repulsion phases, it is to be expected that both alleles of both genes will be maintained in equilibrium. It is therefore suggested that the polymorphisms of Limicolaria are balanced rather than transient in most populations. This conclusion is strengthened by the fact that the banding polymorphism in another species of Limicolaria ( $L$. martensiana) is of ancient origin, since it is found in Pleistocene populations (Owen, 1963).

\section{Summary}

1. Limicolaria aurora and L. flammulata are polymorphic for the shell colour characters banding and background colouration. Banded is dominant to unbanded (the gene $U, u$ ); pink and brown backgrounds are dominant to grey (the gene $G, g$ ). There may be a third gene which controls the darkness of bands. These genes are tightly linked.

2. In several $L$. aurora populations there are fewer banded pink and unbanded grey snails than expected on the basis of Hardy-Weinberg equilibrium.

3. Estimates of the frequencies of the different chromosomal arrangements of the genes $U, u$ and $G, g$ show that the coupling arrangement $U G$ is rare in all populations and the frequencies of both coupling arrangements are lower than the Hardy-Weinberg equilibrium values.

4. The $U G$ chromosome only occurs in the banded pink phenotype and the unbanded grey phenotype is $u g / u g$. It is therefore suggested that the departures of phenotype frequencies from the Hardy-Weinberg equilibrium values may be caused by selection acting against the coupling arrangements of the genes.

5. Selection is probably acting in a similar manner in L. flammulata.

Acknowledgments.-I especially want to thank Professor P. M. Sheppard, F.R.S., for his encouragement and helpful advice, and for his detailed criticism of the manuscript. I wish to thank Professor J. M. Thoday, F.R.S., for helpful discussions and for allowing me to work in his department while I was on leave from Nigeria. It is a pleasure to acknowledge help received from Professor A. H. ar-Rushdi and Dr A. R. G. Owen. Mr J. M. Reinke and Professor R. L. Wilson of the IBM computer centre, Ibadan University, made possible the estimation of chromosome frequencies by computer. Finally, I would like to thank my technician, Mr Moses Oseroghu, for his invaluable assistance.

\section{REFERENCES}

GAIN, A. J., KING, J. M. B., AND ShePPARD, P. M. 1960. New data on the genetics of polymorphism in the snail Cepaea nemoralis L. Genetics, 45, 393-411.

CAIN, A. J., AND SHEPPARD, P. M. 1957. Some breeding experiments with Cepaea nemoralis (L). 7. Genet., 55, 195-199.

CePpellini, R., SINISCALCO, M., AND SMITH, C. A. B. 1955. The estimation of gene frequencies in a random-mating population. Ann. Hum. Genet., 20, 97-115.

FISHER, R. A. 1939. Selective forces in wild populations of Paratettix texanus. Ann. Eugen. Lond., 9, 109-122.

FISHER, R. A., AND DIVER, C. 1934. Crossing-over in the land snail Cepaea nemoralis, Nature, 133, 834-835.

haldane, J. B. s. 1930. A note on Fisher's theory of the origin of dominance and on a correlation between dominance and linkage. Amer. Nat., 64, 87-90. 
LAмотте, м. 1951. Recherches sur la structure génétique des populations naturelles de Cepaea nemoralis (L). Bull. Biol. France, Suppl. 35, 1-239.

LANG, A. 1912. Vererbungswissenschaftliche miszellen. Zeit. f. ind. Abst. u. Vererb., 8, 233-283.

LI, c. c. 1955. Population Genetics. Chicago Univ. Press, Chicago.

OWEN, D. F. 1963. Polymorphism in living and Pleistocene populations of the African land snail Limicolaria martensiana. Nature, 199, 713-714.

RACE, R. R., AND SANGer, R. 1962. Blood Groups in Man. 4th Edition. Blackwell, Oxford. SHEPPARD, P. M. 1953. Polymorphism, linkage and the blood groups. Amer. Nat., 87, 283-294.

Sмгтн, с. A. B. 1956. Counting methods in genetical statistics. Ann. Hum. Genet., 21, 254-276.

TAYLOR, G. L., AND PRIOR, A. M. 1938. Blood groups in England. II. Distribution in the population. Ann. Eugen. Lond., 8, 356-361.

waddington, с. н. 1957. The Strategy of the Genes. Allen and Unwin, London. 